\title{
Partner and Localizer of BRCA2
}

National Cancer Institute

\section{Source}

National Cancer Institute. Partner and Localizer of BRCA2. NCI Thesaurus. Code C84991.

Partner and localizer of BRCA2 (1186 aa, $131 \mathrm{kDa}$ ) is encoded by the human PALB2 gene. This protein may play roles in cell cycle checkpoints and the repair of damaged DNA resolved by recombination. 